be and, in the case of subscription and theatre-TV, already have been expended in the development and perfection of new transmission techniques. Certainly the present Commission policy of refusing to conduct hearings concerned with "mere paper ideas" should be reconsidered. ${ }^{93}$ Viewed in relation with the history of radio, TV's problems seem to warrant separate legislative treatment.94

\title{
THE PEWEE CASE-COMPENSATION FOR SEIZURE OF A GOING BUSINESS
}

Though the "national emergency" strike may be a rarer occurrence than one might suppose, ${ }^{x}$ there is little doubt that government seizure of struck or strikethreatened businesses was an extremely useful technique for maintaining uninterrupted production in important industries during World War II and the reconversion period. ${ }^{2}$ But if the technique was useful, it was also ill-defined. Indeed, as one observer has noted, "There is ground for suspecting that the Government consciously avoided any formulation of rules or principles relating to seizure." 3 The Supreme Court, equally reticent for the most part, has done its defining piecemeal. In United States v. United Mine Workers, ${ }^{4}$ for example, the Court refused to define the relationship between the government and the owner of a seized coal mine, and held that as between the government and the employees an employer-employee relationship existed for some purposes but might not exist for others. In United States v. Pewee Coal Co., ${ }^{5}$ a case arising out of the seizure of the nation's coal mines in I943 (but not decided until I95I), the Supreme Court was called upon to define the relationship between the government and the owner of a seized business. Confusion rather than definition was the result. ${ }^{6}$

The specific question confronting the Court in the Pewee case was: Who bears the losses when a business is temporarily seized by the government and continued in operation for profit largely under the management of the owner? The Pewee Coal Company was seized by the government on May I and held until

${ }_{93}$ See Radio Corp. of America v. United States, 34I U.S. 4I2, 420-42I (I95I).

94 Meanwhile, the forthcoming decision of the Supreme Court in the "captive radio" case may contain some meaningful implications. Pollack v. Public Utilities Commission of the District of Columbia, I9I F. 2d 450 (App. D.C., I95I), cert. granted 72 S. Ct. 77, 80 (I951). In the usual arrangement, the transit company enters into a contract with a middleman to install FM receivers in public transportation vehicles at no cost to the utility, both parties securing their income on a concurrent arrangement with the FM broadcasting station. The commuters thus ride to the chant of LSMFT. The Court of Appeals held the operations violative of the Fifth Amendment. Ibid. For an excellent discussion, see Shipley, Some Constitutional Aspects of Transit Radio, Ir F.C. Bar J. 150 (1950).

× Warren, Thirty-Six Years of "National Emergency" Strikes, 5 Indust. \& Lab. Rel. Rev. 3 (I95I).

"Teller, Government Seizure in Labor Disputes, 6o Harv. L. Rev. Ior7 (I947).

3 Ibid., at ro54.

${ }^{5} 34$ I U.S. II4 (I95I).

4330 U.S. 258 (1947).

${ }^{6}$ See Business Week, p. 30 (May 5, I95I). 
October I2, I943 in order to end a strike of its miners and to insure the continued production of its coal. 7 Pewee's president was appointed the agent of the government to run the mine and during the period of governmental control received various directives, such as orders to fly the American flag, to post placards reading "United States Property" on company premises, and to keep separate books for the period of government operations. But the only directive which substantially interfered with the conduct of Pewee's business was an order for the payment of a wage increase in accordance with a decision of the War Labor Board..$^{8}$ The increase was paid by Pewee and during the period of governmental control amounted to $\$ 2,24$ I.26. Total losses in the same period were $\$ 36,128.96$ and Pewee sued in the Court of Claims to recover this amount.9 It asked for the $\$ 36$, I 28.96 not as compensation for the use of its property but as reimbursement for losses which should have been borne by the government but which were, in fact, borne by the company. ${ }^{\text {. }}$

The Court of Claims, although it held that Pewee's property was "taken" within the meaning of the Fifth Amendment, ${ }^{\text {II }}$ refused to allow the claim for $\$ 36,128.96$ but did award Pewee $\$ 2,24$ I.26 on the theory that the government must bear only that part of operating losses caused by its actions..$^{\mathrm{I2}}$ Certiorari was granted upon application by the government..$^{x 3}$ Pewee, however, did not

7 Exec. Order No. 9340, 8 Fed. Reg. 5695 (I943); "Order for Taking Possession" of the Secretary of the Interior, Order No. I810, 8 Fed. Reg. 5767 (I943). The executive order which directed the seizure of the mines did not refer to any specific statutory authorization for such action but read: "Now, therefore, by virtue of the authority vested in me by the Constitution and laws of the United States, as President of the United States and Commander in Chief of the Army and Navy, it is hereby ordered as follows: ..." However, the Selective Training and Service Act of 1940 , passed on September I6, I940, did provide the President with authority to seize companies which refused to comply with government orders for products or materials. Mines were not mentioned. Selective Training and Service Act of 1940 , at $\$ 9,54$ Stat. 885 (1940), 50 U.S.C.A. App. $\$ 309$ ( 1944 ). This section was amended on June $25,1_{943}$, after the seizure of Pewee and other mines, by the passage of the War Labor Disputes Act, which added to Section 9 of the Training and Service Act a paragraph empowering the President to seize any vital plant or mine whose operations had stopped or were threatened with stoppage because of a labor dispute. War Labor Disputes Act, at $\S 3,57$ Stat. r63 (1943), 50 U.S.C.A. App. $\$ \S 309$, I $5_{3} 3$ (I944). See, for discussions of the President's seizure powers, National Emergencies and the President's Inherent Powers, 2 Stanf. L. Rev. 303 (I950); Teller, Government Seizure in Labor Disputes, 60 Harv. L. Rev. Ior7, I040-44 (r947). For a discussion of proposed legislation, see the note in 37 Cornell L.Q. 9I (I95I).

${ }^{8}$ Findings 8 and I2, Pewee Coal Co. v. United States, I I5 Ct. Cl. 626, 642, 650 (I950). The War Labor Board Order may be found in 9 War Lab. Rep. II2 (1944). The Board was created by Exec. Order No. 9017, 7 Fed. Reg. 237 (I942). Section 5 of the War Labor Disputes Act provides, "Any such order of the Board shall, upon approval by the President, be compiled with by the Government agency operating such plant, mine, or facility." 57 Stat. 163 (1943), 50 U.S.C.A. App. \& 1505 (I944).

9 Pewee Coal Co. v. United States, 88 F. Supp. 426 (Ct. Cl., r950).

to Brief for the Plaintiff at $18 \mathrm{r}-82$.

II ". . nor shall private property be taken for public use, without just compensation."

U.S. Const. Amend. 5 .

Iz Pewee Coal Co.v. United States, 88 F. Supp. 426, 43I (Ct. Cl., I950).

${ }_{3}$ United States v Pewee Coal Co., 340 U.S. 808 (I950). 
seek review, and therefore the question before the Supreme Court was whether the Court of Claims erred in allowing Pewee $\$ 2,24$ r.26, not whether there was error in refusing to allow $\$ 36, \pi 28.96$.

The Supreme Court, in a 5-4 decision, affirmed the Court of Claims. ${ }^{\text {I4 }}$ Two opinions were written in support of the decision, one of which, Justice Reed's, agreed with the theory of the Court of Claims. The other, by Justice Black, with Justices Douglas, Frankfurter, and Jackson concurring, would have awarded the full $\$ 36,128.96$, had a claim for this amount been before the Court, on the theory that since the government had taken Pewee's business it was responsible for the subsequent operation of that business. Because, however, the disposition of total losses was not a question before the Court, these Justices also voted to affirm the Court of Claims decision. Justice Burton, writing a dissenting opinion in which Chief Justice Vinson and Justices Clark and Minton concurred, would have reversed the Court of Claims and allowed Pewee nothing, apparently on the theory that the government had not fully taken Pewee's business and that Pewee was therefore obliged to prove what it had lost because of the government action, a burden which it had failed to sustain. Thus, although all nine Justices agreed there had been a "taking" of Pewee's property, they disagreed as to the nature and consequences of that "taking." $\dot{A}$ majority of five Justices held that Pewee should be awarded some of its losses and a different majority of five Justices held that the government should not bear total operating losses, Justice Reed's position placing him in both groups.

It was the theory of Justice Black's opinion that the government took the right to operate the Pewee coal business and, as an incident of that taking, the right to retain the profits and the obligation to bear the losses of its operations. ${ }^{\text {ss }}$ It was also a part of this theory that the proper measure of compensation for the temporary taking of Pewee's business was the fair rental value of the business for the period of government control. ${ }^{16}$ On this view, the government's status as temporary proprietor was not changed because it chose to appoint Pewee's president its agent to run the mine instead of ousting the management and appointing other agents. Similarly, no weight would be given to the fact that the government clearly did not intend to become temporary proprietor with the right to retain profits and the obligation to bear losses. ${ }^{17}$ The crucial fact was that the

14 United States v. Pewee Coal Co., 34I U.S. II4 (I95I).

"s "It follows almost as a matter of course from our holding in United Mine Workers that the Government here 'took' Pewee's property and became engaged in the mining business. ... Whatever might have been Pewee's losses had it been left free to exercise its own business judgment, the crucial fact is that the government chose to in tervene by taking possession and operating control. By doing so, it became the proprietor and, in the absence of contrary arrangements, was entitled to the benefits and subject to the liabilities which that status involves." United States v. Pewee Coal Co., 34I U.S. II4, II6-I7, II8-I9 (I95I).

${ }^{16}$ Ibid., at II 7 .

${ }^{27}$ The Coal Mines Regulations, Section 603.5(b), 8 Fed. Reg. 6655 (1943); Letter of the Director of Production of the Solid Fuels Administration to Pewee's president, July 3I, I943, Trans. Rec. at 660-6I, Pewee Coal Co. v. United States, II 5 Ct. Cl. 626 (I950). 
government "took" the mine, as evidenced by the language of the seizure orders. $^{18}$

Under Justice Black's theory, then, the situation was analogous to that of a lease relationship, Pewee being the lessor and the government the lessee of the business. Pewee, however, did not ask rental value for the use of its property; it asked, rather, to be reimbursed for operating losses sustained by it while its property was being used by the government. Under the "lease" analogy these losses should have been borne by the government, as they would have been borne by an ordinary lessee of the business; and, had Pewee requested certiorari, an application of this theory of the taking would have resulted in an

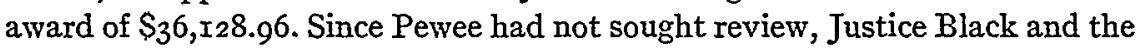
Justices concurring in his opinion voted to affirm the Court of Claims decision.

In thus applying the lease theory to the Pewee case, Justice Black was not required to discuss the problem of measuring rental value. Nonetheless, his opinion states, "The Government's profit and loss experience may well be one factor involved in computing reasonable compensation for a temporary taking." ${ }^{19}$ To take account of this factor, where losses sustained during government operations were unforeseeable, would be to depart from a strict lease theory, for an ordinary lessee would pay rent based on his expectation of profit at the time of the leasing. Where losses were foreseeable, however, Justice Black could, consistently with his theory, treat losses as a factor in the determination of rent and probably even uphold a finding of zero rental value.. ${ }^{20}$

Application of the lease theory where the seized business returned a profit would allow the government to keep the profits and, of course, obligate it to pay rent. If the rental value were said to be equal to net profits (after the payment of WLB-approved wage increases) during government operation, owners would be placed in a difficult bargaining position. Employees would know that if the owner refused to pay higher wages, the government, after a seizure made necessary by a strike, would pay them and pay them with company funds. Labor would thus be given an incentive to strike. ${ }^{2 x}$ But this consideration does not operate more strongly against the lease theory than against any other, for, on

${ }^{88}$ United States v. Pewee Coal Co., 34I U.S. II4, Ir5-I6 (I95I).

$x 9$ Ibid., at $x \times 8$.

${ }^{20}$ As to the foreseeability of Pewee's losses, see Findings ${ }_{5} 5$ and $I 6$, Pewee Coal Co. v. United States, II 5 Ct. Cl. 626, 658-64 (I95O). Because Justice Black uses the phrase "operating losses" throughout, it is likely that the losses he would require the government to bear do not include ordinary depreciation and depletion costs. These would, of course, enter into a determination of rental value. See Kimball Laundry Co. v. United States, 338 U.S. I, 4 (I949).

ax If the formula used to determine the rent usually resulted in an award lower than net profits, owners would be placed in the still more difficult bargaining position of having to grant labor's demands to avoid a strike or run the risk of a seizure which would divest them of a portion of expected profits. Nevertheless, rental value might reasonably be determined to be less than the net profits because of the shift of the entrepreneurial risk to the government. This would, of course, increase the willingness of a particularly sanguine owner to pay the higher wages demanded. 
the assumption that during an emergency government will not allow a strike in a vital industry to continue, labor will always have a greater incentive to strike than in the usual bargaining situation where, if wage demands are too high, the employer will at least temporarily close shop. And even this observation would be accurate only so long as a government wage award-a War Labor Board order, for example-no matter by whom it was paid, would be likely to amount to more than the employees could get through collective bargaining with the owner.

Justice Burton's theory of the taking must be inferred because it is not stated explicitly. From a reading of the dissenting opinion, it is not clear what the government had taken.22 Apparently, however, it was the view of the dissenting Justices that the government had not ousted Pewee from possession and control of its mine and that therefore Pewee had not lost that use of its property for which rental value is a proper measure of compensation. In this view, Pewee would recover nothing unless there were a showing that it would have lost less than $\$ 36,128.96$ had the government not taken its property. Whereas Justice Black emphasized the language of the seizure orders, the dissenting opinion would seem to give greatest weight to the circumstance that Pewee remained in physical possession of its property and, in every respect but one, retained usual managerial prerogatives and continued to make managerial decisions. ${ }^{23}$

It was evidently Justice Burton's view, then, that since Pewee had not lost the use of its property, it must show what loss it did suffer because of the government taking. ${ }^{24}$ According to the dissenting opinion, this could be done only by showing that greater losses had been sustained as a result of the taking than would have been sustained in the absence of a taking. This, of course, makes proof of compensable loss a practical impossibility, for an owner will only operate his business where it is profitable for him to do so. Therefore, where business operations are discontinued solely because of a strike, the owner of such a business could not show that he had been harmed by a government seizure which put the struck plant back into operation and which made it unnecessary for him to bear the financial burden of an idle business. ${ }^{25}$ Nor could he ordinarily prove that benefits greater than this burden would have resulted from his strike strategy without a showing of when the strike would have ended and on what terms - an impossible burden of proof. In the dissenting view, then, companies which had been seized because of a strike, but whose officers had retained sub-

${ }^{22}$ See the suggestion in the Brief for the United States on writ of certiorari to the Court of Claims in the Pewee case, at 53.

${ }^{23}$ For the situation when the government "really" takes a business, see the Brief for the United States on writ of certiorari to the Court of Claims, at 36, United States v. Wheelock Bros., Inc, 34I U.S. $3^{\text {Ig }}$ (195I).

24 United States v. Pewee Coal Co., 34I U.S. II4, I22 (I95I).

25 Benefits to the claimant are to be recognized in measuring just compensation. United States v. Miller, 3 I 7 U.S. 369,376 (I943). See Brief for the United States on writ of certiorari to the Court of Claims in Pewee, at 89-95. 
stantially complete managerial control, could not recover compensation for the seizure.

One cannot ascertain whether Justice Burton would continue to treat the government's action as a noncompensable taking where the owner was dispossessed of his plant and ousted from management. ${ }^{26}$ But it is likely that he would not do so if the taking were as complete as the taking of motor carriers by the government during World War II, where the government ousted company officers and replaced them with government employees, transferred company funds to a government account, took out licenses in its own name, and in general asserted complete operational control..$^{27}$ Under these circumstances the fact of the loss of the use of property for which rental value is the measure of compensation could easily be established. In any case, it is clear that for Justice Burton the taking of a small degree of managerial control is not such a taking of the use of business property as will justify recovery of rental value. To recover for the taking of a limited degree of control, as in the Pewee case, the owner must prove what financial loss the taking caused. At some point so much control would be taken as to amount to a taking of the use of the business and rental value would be recoverable. The Pewee case did not require Justice Burton to announce precisely where he would draw the line.

Justice Reed's opinion, like the dissent, refuses to treat the government as a lessee because the full use of the property was not taken by the government. Justice Reed distinguishes between a taking "in which the owners are ousted from operation, their business suspended, and the property devoted to new uses ..."28 and the taking of the Pewee Coal Company which did not involve the ousting of the owners from operation but only the taking of "the responsibility of its [the property's] direction and employment" and the "supervision of a losing business,"29 not the use of property. This latter, "supervisory" kind of taking, according to Justice Reed, "ought not to place upon the Government the burden of the losses incurred during that supervision unless the losses were incurred by governmental acts, e.g., if the business would not have been conducted at all but for the Government, or if extra losses over what would have been otherwise sustained were occasioned by Government operations. Where the owner's losses are what they would have been without the 'taking,' the owner has suffered no loss or damage for which compensation is due." $3^{\circ}$

\footnotetext{
${ }^{26}$ An owner could, of course, refuse to pay the ordered wage increase, preferring to allow the strike to continue rather than pay higher wages. It is likely that one effect of such a refusal would be to dispossess him of his plant. The government's objective in plant seizure is to insure the continued operation of the vital business which it seizes, and it is not more likely to permit the frustration of its objective by the recalcitrance of an owner than by his employees. See The Coal Mines Regulations, Section 603.3I, Removal of Operating Managers, 8 Fed. Reg. 6657 (I943). With regard to motor carriers, see Wheelock Bros., Inc. v. United States, 88 F. Supp. 278, 28I (Ct. Cl., 1950).

${ }^{27}$ See note 23 supra.

${ }^{28}$ United States v. Pewee Coal Co., 34I U.S. II4, I20 (I95I).

${ }^{29}$ Ibid., at 120 , I 21 .

${ }^{30}$ Ibid., at $\mathrm{x} 2 \mathrm{I}$.
} 
But it is difficult to reconcile these statements about compensation with the conclusion that the Court of Claims award of $\$ 2,24$ I.26 was proper under the circumstances..$^{3 \mathrm{I}}$ The sentence last quoted above would seem, like Justice Burton's opinion, to place upon the company the burden of showing that its losses were greater than what they would have been without the taking-a showing not made by Pewee. Presumably Justice Reed would base the award of the $\$ 2,24$ T.26 on the second of his two illustrations of "losses incurred by governmental acts," for this sum, which "was expended without legal or business necessity to do so" he calls an "extra allowance." ${ }^{2}$ That it was expended without business necessity seems questionable, at least if it is a legitimate business objective to keep operations going. In what sense the expenditure was "extra" is not made clear. Manifestly, "extra losses" refers, in the Pewee case at least, to the cost of obeying a specific government directive. Justice Reed would thus substitute the showing of this cost for the burden of proving financial harm caused by the taking of less than the full use of a losing business. The effect of this view would be to put upon the government the burden of paying for wage increases which Justice Burton would have the owner bear.

One can only speculate as to whether Justice Reed's view would remain unchanged if the seized business were a profitable one. (If the owner is to be compensated for the increase in losses due to extra wage payments, why not also for a decrease in profits?) But if the government were required to bear the cost of wage increases in all seized businesses, seizure would become a very expensive and much less useful technique. Indeed, by furnishing an incentive to the owner of a vital business to refuse to pay higher wages in the hope that through a seizure the government could be made to pay for them, such a requirement would tend to bring about the very strike which seizure was designed to prevent.

Although Justices Burton and Reed both agree that the government "took" Pewee's property ${ }^{33}$ neither is willing to burden the government with all the con-

${ }^{31}$ The opinion merely states, "Here the Court of Claims has correctly applied these principles. ..." Ibid.

${ }^{32}$ Ibid. Had Justice Reed intended to base the award on the first of his two illustrations (i.e., losses incurred during the period of governmental supervision if the business would not have been conducted at all but for the government), it would have been necessary to determine what Pewee's financial position would have been had it remain ed idle, which the opinion does not do. Nor does the opinion indicate why this first illustration of a loss incurred by governmental acts is not an illustration of the Pewee situation. Because the Pewee mine was idle before the taking, there was no evidence that a private settlement of the strike was foreseeable, and the government taking was intended to have and did have the effect of putting the mine back into operation immediately, without waiting for the dispute to be solved by collective bargaining. Either Justice Reed assumes the strike would shortly have been settled or simply refuses to recognize its existence for the purpose of measuring compensation. In any case, he is evidently unwilling to equate a stoppage due to a strike with a situation in which "the business would not have been conducted at all but for the government."

33 Perhaps they were impelled to reach this conclusion by the Court's finding in United States v. United Mine Workers of America, 330 U.S. 258 (1947), that the government had "seized actual possession of the mines," that the government was operating the mines, and that 
sequences of a taking. Neither therefore is willing to state precisely what interest in property the government took nor to measure the value of its use. Justice Burton, though he agrees "there was a 'taking' of the mining property,",34 implicitly rejects this interpretation of the government's action by his refusal to compensate Pewee for losses. If Pewee's property was legally taken, Pewee could not logically be held responsible for what was done with the property after it had passed into the hands of the taker. ${ }^{35}$ That Justice Reed would hold Pewee only partly responsible does not relieve him of the contradiction. In fact he seems to negate his admission of a taking explicitly by saying that "the Government ... 'takes' the property in the sense of assuming the responsibility of its direction and employment for national purposes. ..." ${ }^{66}$ Under some circumstances the assumption of responsibility might constitute a taking, under others not. But an examination of government acts to determine whether they constitute a taking is a matter separate from the determination of the compensation to be paid for a taking. The measure of this amount where property is taken temporarily is the rental value of the property taken. ${ }^{37}$ Clearly the $\$ 2,24 I .26$ which Justice Reed would award ás just compensation was not meant to measure the rental value of any property taken from Pewee.

There have been few other cases on the measure of compensation for the temporary taking of an operating business. In Anderson v. Chesapeake Ferry Co. $3^{38}$ Justice Black's lease theory was adopted. The State of Virginia had seized a strike-bound ferry company, ousted the owners from control, and operated the ferry company through the State Highway Commissioner pursuant to statutory authority. ${ }^{39}$ The company sued for the net profits for the period of temporary operation as just compensation for the taking of its business, but the Supreme Court of Virginia disallowed its claim. It said the measure of just compensation could not be profits, for even if there had been losses the taker would have been obligated to pay compensation..$^{\circ} \mathrm{It}$ adopted, as the proper measure of compensation, "the fair market value of the right to use the properties of the ferry company...." 4 Profits made during the period of temporary operation would be admissible, it held, "as bearing on the question of fair rental value." 42

\footnotetext{
"the relationship between the Government and the workers is that of employer and employee." Tbid., at 289. As already noted, however, the Court explicitly declined to pass on the relationship between the government and the owner. Tbid., at 288.

34 United States v. Pewee Coal Co., 34I U.S. II4, I2I (I95I).

35 See, e.g., E. I. Dupont De Nemours \& Co. v. Davis, 264 U.S. 456, 462 (I924).

${ }^{36}$ United States v. Pewee Coal Co., 34I U.S. II4, I20 (I95I).

37 Elements and Measure of Compensation in Eminent Domain for Temporary Use and Occupancy, 7 A.L.R. 2d 1297, 1299-1300 (1950), annotating Kimball Laundry Co. v. United States, 338 U.S. I. (r949).

${ }^{38}$ I86 Va. 48 ז, 43 S.E. 2 d 10 ( 9947 ).

39 Code of Virginia (Michie, 1950 ), $\$ \S 33-202-33-208$.

10 Anderson v. Chesapeake Ferry Co., I86 Va. 481, 492, 43 S.E. 2d Io, I6 (I947).

4 Ibid., at 494, I7. 12 Ibid.
} 
Marion and Rye Valley R. Co.v. United States ${ }^{43}$ was heavily relied upon by the dissenting Justices in the Pewee case. The government by presidential proclamation had "taken" the railroads of the country but, at least in the case of the Marion and Rye Valley Railway, had done nothing to interfere in the operation or management of the business. The owners were not ousted from control of their railway nor were they appointed government agents. Justice Brandeis for the Court did not decide whether the government's action constituted a taking but said that even if it did no compensation could be recovered because nothing of value had been taken. 44

A third case, United States v. Wheelock Bros., Inc., 45 a companion to the Pewee case, was decided by the Court of Claims on the same theory it adopted in its Pewee decision..$^{46}$ But after granting certiorari the Supreme Court found it lacked jurisdiction. ${ }^{47}$

In Kimball Laundry Co. v. United States, $4^{8}$ Justice Black's theory of the nature of a temporary taking of property was clearly stated though the question of the Pewee case was not presented because the government, which temporarily took the claimant's laundry, used it exclusively for the army and not as a business run for profit. The measure of compensation was held to be "the rental that probably could have been obtained." 49 The Court said: "Determination of the value of temporary occupancy can be approached only on the supposition that free bargaining between petitioner and a hypothetical lessee of that temporary interest would have taken place in the usual framework of such negotiations." ${ }_{50}$

The lease theory of a temporary taking was also adopted in what is perhaps the earliest instance of a temporary taking. ${ }^{5 \mathrm{I}} \mathrm{It}$ is at least impliedly accepted by most of the cases involving a temporary taking of property; for, though all the cases do not explicitly call the government a lessee, the measure of compensation is generally said to be the rental value of the property taken..$^{52}$ Except for the Marion, Kimball, Anderson and Wheelock cases, however, these temporary taking cases do not involve the taking of a going business.

Both the Reed and Burton opinions cite the Marion case as justification for dispensing with the rental value rule under the circumstances of the Pewee case. But the claimant in the Marion case did not maintain that, because the railroad company was "taken," the subsequent operation was for the account of the government and that it, the claimant, was entitled to rental value. Instead the Marion Company proceeded inconsistently with this theory; for, though it

43270 U.S. 280 (1926).

44 Ibid., at 282.

${ }^{46}$ Wheelock Bros., Inc. v. United States, 88 F. Supp. 278,283 (Ct. Cl.; r950).

47 United States v. Wheelock Bros., Inc., 34I U.S. 3I9, 320 (I95I).

${ }^{8} 338$ U.S. I (1949). $\quad 49$ Tbid., at $7 . \quad 50$ Ibid.

5x Johnson v. United States, 2 Ct. Cl. 39I, 4 I6 (r866).

${ }^{52}$ See note $2 I$ supra. 
claimed compensation for the use of its property, it retained the profits from operations and did not offer to give them up to the taker. Under these circumstances it is difficult to see how the Marion decision can be said to govern Pewee's claim. Rather, it would appear that both the Reed and Burton opinions are inconsistent with the theory of a taking of property.

On the other hand, both the Anderson and Kimball cases, each of which adopts the lease theory, are easily distinguishable from the Pewee case because in each the owners were ousted from control over their business. Justice Black's opinion, of course, is consistent with the statement, to which all the Justices assented, that the government took Pewee's property. But a majority of the Court did not agree with his conclusion as to what interest in property the government had taken. They therefore were able to give effect to the government's intention to assume the role of employer vis-à-vis the miners, so as to induce them to return to work, but to play, in Justice Reed's language, only "supervisor" or "director" vis-à-vis the owners. And as Justice Black's interpretation of the government's actions rested heavily upon the language of the seizure orders, ${ }^{53}$ a mere change in language might affect the view of some or all of the Justices subscribing to his opinion.

On balance, it would appear that in a future seizure of an operating business where the owners are not ousted from management but retain substantially complete managerial control, the Court would be unlikely to interpret the government's action as a taking of the use of the business and an operation of it for the government's account. To do less, however, would be to face the inconsistency found in the opinions of Justices Burton and Reed-that property may be taken while the responsibility for its operation remains with those from whom it was taken. To escape this inconsistency and to justify abandonment of the rental value measure of compensation and, perhaps, the substitution of some other measure, the Court would almost certainly have to spell out clearly its own interpretation of what the government had done.54 Two courses would seem to be open. The government's contention that its directives to the coal mine managers were within its regulatory powers might form the basis for a theory consistent with both the power to decree a wage increase and operation of the seized business for the company account.ss This would, of course, mean abandonment of the theory of a taking. Or the Court might try, in the manner unsuccessfully attempted by Justice Reed, to formulate grounds for a com-

s3 United States v. Pewee Coal Co., 34I U.S. II4, II5-I6 (I95I).

54 By coincidence, on the same day it handed down its decision in the Pewee case, the Court adopted a new rule of civil procedure relating to the condemnation of property which requires that the plaintiff in a condemnation suit state, among other matters, the interest in property to be acquired. Rule $7 \mathrm{rA}, 34 \mathrm{I}$ U.S. 963 (r95 r).

${ }_{55}$ See the dissenting opinion of Judge Madden in the Wheelock case, 88 F. Supp. 278,284 (Ct. Cl., r950). Compare, Brief for the United States on writ of certiorari to the Court of Claims in Pewee, at 64-67, in Wheelock, at 39-52. See also the note in 64 Harv. L. Rev. $33^{8}$ (r950) on the Wheelock and Pewee decisions. 
promise position between a noncompensable regulation on the one hand, and a complete, traditional taking on the other..$^{56}$

Unquestionably, Pewee has raised significant and perplexing problems. Indeed, it has recently been called "the most important labor case of the year ..." 57 (emphasis supplied). Speculation about possible solutions aside, the problems certainly merit more detailed consideration than the rather cursory glances bestowed upon them in Pewee.

\section{VERTICAL FORESTALLING UNDER THE ANTITRUST LAWS}

Monopolies and restraints of trade have traditionally been thought of in terms of horizontal market power. A recent increase in the number of cases involving exclusive dealing arrangements, resale price maintenance, boycotting practices, tie-ins, certain forms of agency agreements and vertical integration has pointed up the necessity of defining the extent of vertical control permissible under the Sherman, ${ }^{2}$ Clayton ${ }^{2}$ and Federal Trade Commission Acts. ${ }^{3}$ A strong argument can be made that these forms of vertical forestalling ${ }^{4}$ can have adverse effects on free competition only when used as a method of exploiting horizontal monopoly power. The Supreme Court appears to have accepted this argument with respect to vertical integration in recent cases holding that vertical integration is not per se illegal. However, the use of intent and conspiracy doctrines in the integration cases seems to have extended the area of the illegality despite the rejection of a per se rule.

With respect to looser forms of vertical forestalling, the cases state an even broader prohibition. Resale price maintenance is clearly illegal per se, and group boycotts may also fall within the "per se" category. In the field of exclusive supply and tying contracts, the courts have also established broad rules of illegality although a flat ban has not been reached. The cases applying these broad rules have, however, generally involved horizontal market power suf-

${ }^{56}$ For a discussion of the differences between a regulation and a taking, see Governmental Seizure of a Business to Prevent Strike Caused Work Stoppages-Regulation or Taking, I9 Geo. Wash. L. Rev. 184 (I950).

s7 Frank, The United States Supreme Court: 1950-51, I9 Univ. Chi. L. Rev. I65, I67 (1952).

I 26 Stat. 209 ( 1890 ), as amended, I5 U.S.C.A. \$ I et seq. (I95I).

${ }^{2} 38$ Stat. 730 (IgI4), as amended, 15 U.S.C.A. $\$ 12$ et seq. (I95 $\mathrm{r}$ ).

${ }^{3} 38$ Stat. $7 \mathrm{I} 7$ (IgI4), as amended, I5 U.S.C.A. $\$ 4 \mathrm{I}$ et seq. (I95I).

"For the purposes of this comment, the phrase "vertical forestalling" will be used as a generic phrase covering vertical control in all its forms ranging from outright vertical integration on the one extreme to exclusive dealing contracts and resale price maintenance on the other. At common law, "forestalling" referred to the exclusion of goods or traders from a market. Schueller, The New Antitrust Illegality Per Se: Forestalling and Patent Misuse, $50 \mathrm{Col}$. L. Rev. 170, 176-79 (1950). With the exception of resale price maintenance, these forms of vertical control involve the exclusion of outsiders from a certain market. Hence, he phrase "vertical forestalling." 